Research article

\title{
Pharmacological screening of Gymnanthemum coloratum (Willd.) H. Rob. \& B. Kahn (Compositae) and Terminalia ivorensis A. Chev. (Combretaceae) from DR Congo: Spotlight on the antisickling, antibacterial and anti-diabetic activities
}

\author{
Gédéon Ngiala Bongo ${ }^{1}$, Koto-te-Nyiwa Ngbolua ${ }^{1,2,3 *}$, Colette Masengo Ashande ${ }^{2}$, Kevin \\ L. Karume ${ }^{1}$, Janvier Mukiza ${ }^{4}$, Dorothée D. Tshilanda ${ }^{5}$, Damien S.T. Tshibangu ${ }^{5}$, \\ Nadège K. Ngombe $^{6}$, Théophile F. Mbemba ${ }^{1}$ and Pius T. Mpiana ${ }^{5}$ \\ ${ }^{1}$ Département de Biologie, Faculté des Sciences, Université de Kinshasa, B.P. 190 Kinshasa XI, République \\ Démocratique du Congo \\ ${ }^{2}$ Département des Sciences de l'Environnement, Faculté des Sciences, Université de Gbadolite, B.P. 111 Gbadolite, \\ Province du Nord Ubangi, République Démocratique du Congo \\ ${ }^{3}$ Institut Supérieur Pédagogique d'Abumombazi, Province du Nord Ubangi, République Démocratique du Congo \\ ${ }^{4}$ Department of Biochemistry, Faculty of Medicine and Surgery, University of Gitwe, Nyanza, Republic of Rwanda \\ ${ }^{5}$ Département de Chimie, Faculté des Sciences, Université de Kinshasa, B.P. 190 Kinshasa XI, République \\ Démocratique du Congo
}

${ }^{6}$ Faculté des Sciences Pharmaceutiques, Université de Kinshasa, Kinshasa XI, République Démocratique du Congo *Corresponding Author: jpngbolua@unikin.ac.cd

[Accepted: 25 November 2017]

\begin{abstract}
In Democratic Republic of the Congo (DRC), it was reported a rare association in a patient, of two genetic diseases namely sickle cell anemia and diabetes which have a common denominator that is to make patients susceptible to infections. They constitute a serious public health problem in Africa. Given the difficult and limited management of these diseases, the use of Traditional Medicine and medicinal plants can be an effective alternative. The leaves of both Gymnanthemum coloratum and Terminalia ivorensis were collected in 2014 in Kinshasa city and Gbadolite city (Nord Ubangi province) respectively and were selected through chemotaxonomic approach. The bacterial strains used for assessing the antibacterial were Staphylococcus aureus and Escherichia coli and mice for the antidiabetic activity. The phytochemical screening showed the presence of total polyphenols, tannins, flavonoids, linked quinones, saponins, leucoanthocyanins, alkaloids and anthocyanins. The organic extracts of G. coloratum and $T$. ivorensis showed an antisickling activity. Only $S$. aureus was sensitive to the leaves of $T$. ivorensis (MIC $<62.5 \mu \mathrm{g} \cdot \mathrm{mL}^{-1}$ ) and G. coloratum (MIC $\leq 250 \mu \mathrm{g} \cdot \mathrm{mL}^{-1}$ ) while no effect was observed on $E$. coli. The mean values for glycemia in treated and untreated mice after 2 hours were $62 \pm 14.3$ mg. $\mathrm{dL}^{-1}$ (Glibenclamide $20 \mathrm{mg} \cdot \mathrm{Kg}^{-1}$ ) and $70.4 \pm 16.6 \mathrm{mg} \cdot \mathrm{dL}^{-1}$ (ethyl acetate extract of T. ivorensis $500 \mathrm{mg} \cdot \mathrm{Kg}^{-1}$ ). To our knowledge, it is for the first time that the antisickling activity of $G$. coloratum and T. ivorensis is reported thus validating the chemotaxonomic approach used as a criterion for selecting these two plants. It is also for the first time that anti-hyperglycaemic activity of $T$. ivorensis is reported.
\end{abstract}

Keywords: Sickle cell anemia - Diabetes - Chemo-taxonomic approach.

[Cite as: Bongo GN, Ngbolua K-te-N, Ashande CM, Karume KL, Mukiza J, Tshilanda DD, Tshibangu DST, Ngombe NK, Mbemba TF \& Mpiana PT (2017) Pharmacological screening of Gymnanthemum coloratum (Willd.) H. Rob. \& B. Kahn (Compositae) and Terminalia ivorensis A. Chev. (Combretaceae) from DR Congo: Spotlight on the antisickling, antibacterial and anti-diabetic activities. Tropical Plant Research 4(3): 441-448]

\section{INTRODUCTION}

In Democratic Republic of the Congo (DRC), it has been recently reported that a rare association in a patient, 
of two genetic diseases, namely sickle cell disease and diabetes, diseases that constitute a serious public health concern worldwide (Kamba et al. 2014). Sickle cell anemia is characterized by the presence of hemoglobin S in the blood (Ngbolua 2012, Mpiana et al. 2013), and it is the first genetic disease in Africa by the number of patients and it is clinically manifested by a vaso-occlusion and hemolytic anemia, resulting from the polymerization of hemoglobin S molecules into tactoids (Ngbolua 2012).

Diabetes, on the other hand, is characterized by hyperglycaemia (sugar content $>1.2 \mathrm{~g} \cdot \mathrm{dL}^{-1}$ on an empty stomach), hyper-ketone (keto acid > $3 \mathrm{mmol} . \mathrm{L}^{-1}$ ), an acid-base and hydro-electrolytic imbalance. At the muscular level, there is a real competition between free fatty acids and glycose to be oxidized: free fatty acids are oxidized in priority, leading to an increased production of acetyl CoA which in turn inhibits glycolysis enzymes (Declerck 2002). Thus, the storage and use of glycose are decreased at the muscular level while there is a stimulation of gluconeogenesis in the hepatic level and all of this contributes to increase the blood glucose (Declerck 2003, De boeck et al. 2012).

Given the difficult and limited management of sickle-cell anemia and diabetes in DRC, the use of traditional medicine and medicinal plants can be an effective alternative in the management of both diseases in emergency situations. According to the World Health Organization (WHO), more than $80 \%$ of the population living in poor areas in Africa uses medicinal plants to treat themselves (Kolling et al. 2010, Mangambu et al. 2012). Several scientific works carried out in DRC and elsewhere highlight the antisickling and antidiabetic properties of various plants (Katemo et al. 2012, Ngombe et al. 2013, Masunda et al. 2014, Ngbolua et al. 2014a, b, c, d, e, Kasali et al. 2016).

In the present study Gymnanthemum coloratum and Terminalia ivorensis were used which were selected using a chemo-taxonomic approach. In fact, some species of Vernonia and Terminalia genera are known for their antisickling and antidiabetic properties (Mbodj 2003). Following this approach, it should therefore be expected that $T$. ivorensis shows antisickling and antidiabetic activities while G. coloratum (Syn Vernonia colorata) with antidiabetic properties is expected to show an antisickling activity. In addition, both hypotheses (antisickling and antidiabetic activities) are validated, given that diabetes and sickle-cell anemia have a common denominator which is to make patients susceptible to infections (Ngbolua 2012), henceforth both plants have to show an in vitro antibacterial activity. The main objective of this study was to provide the scientific rationale of what the ethnomedical use of these two plants would represent. And, the specific objectives were to perform a phytochemical screening of aqueous extracts of these two selected plants, to subject the leaf powders to fractional extraction using increasingly polar solvents (petroleum ether, ethyl acetate and methanol) and last to assess the antisickling, antibacterial and anti-hyperglycemic activities of organic extracts. The significance of this research is to value the use of medicinal plants in the treatment and management of sickle cell disease and diabetes.

\section{MATERIALS AND METHODS}

\section{Plant materials}

Plant materials used were leaves of Gymnanthemum coloratum and Terminalia ivorensis A. Chev. collected at Makala commune in Kinshasa and Gbadolite in Nord Ubangi province respectively. G. coloratum was identified in the Herbariun of Faculty of Sciences, University of Kinshasa while while T. ivorensis was identified a botanist from "Centre de Surveillance de la Biodiversité", University of Kisangani. Blood samples used for assessing the antisickling activity of plant extracts were taken from a sickle cell adolescent patient at the "Centre de Médecine Mixte et d'Anémie SS" of Kinshasa. Bacterial strains used were provided by the Laboratory of Microbiology, Faculty of Pharmaceutical Sciences (University of Kinshasa) and mice were provided by the National Institute of Biomedical Research (NIRB).

\section{Methods adopted}

\section{A. Collection and conditioning of plant material}

Plant samples were collected in 2014 in Kinshasa and Gbadolite, in the province of Nord-Ubangi respectively. After collection, leaves were washed with tap water and dried under shade for one month, and then crushed separately in a shredder (Moulinex brand). The powders obtained were sieved in order to obtain fine powders.

\section{B. Extraction with solvent of increasing polarity}

Fifty grams of powder of each species were macerated in petroleum ether, ethyl acetate, and methanol (1:10, 
w/v) respectively for 48 hours. After filtration, various extracts were evaporated to dryness using a rotary evaporator apparatus at $37^{\circ} \mathrm{C}$.

\section{Phytochemical Screening}

The phytochemical screening was carried out according to the standard protocol as described by Bruneton (1999), and it can be performed in aqueous or organic phases.

\section{Biological experiments}

\section{a. Emmel test}

The total SS blood previously diluted in saline solution $(\mathrm{NaCl} 0.9 \%)$ by reason of four to eight drops of the saline solution. On a slide was placed a drop of diluted blood brought into contact with a drop of the drug along with a drop of sodium meta-bisulfite $\left(\mathrm{Na}_{2} \mathrm{~S}_{2} \mathrm{O}_{5} \%\right)$.

The mixture obtained constitutes the microscopic preparation, and it is then covered with a coverslip and is super-cooled by paraffin put on the edges of the slide. The solutions of our extracts (petroleum ether, ethyl acetate and methanol) are prepared by dissolving a few $\mathrm{mg}$ of these extracts in the saline solution. Different preparations obtained were observed with the OLYMPUS optical microscope at 10X and $40 \mathrm{X}$ magnifications after 24 hours (Ngbolua et al. 2014a, b, c, d).

\section{b. Antibacterial assay}

The antibacterial activity was evaluated by the microdilution method in a liquid medium.

\section{i. Preparation of the stock solution}

In a sterile test tube, place $0.020 \mathrm{~g}$ of each extract diluted in $250 \mu \mathrm{L}$ of DMSO then stir for 10 minutes and add $5 \mathrm{~mL}$ of Mueller Hinton culture medium using a pipette and mix.

\section{ii. Preparation of the bacterial suspension}

Place $2 \mathrm{~mL}$ of the saline solution into two sterile test tubes. Using a sterile platinum loop, take two isolated colonies of two strains to be tested namely Escherichia coli ATCC 27195 and Staphylococcus aureus ATCC 33591 and place each colony in the saline solution in both tubes. This bacterial suspension is diluted in the appropriate culture medium at a rate of $9 \mathrm{~mL}$.

iii. Dilution of extracts and inoculation of the microplate

A 96-well sterile polystyrene microplate (8 rows A-H. x 12 columns) with a round bottom was used. Then each well was filled with $100 \mu \mathrm{L}$ of culture medium as follows: $A_{2}$ to $A_{8}, B_{2}$ to $B_{8}, C_{2}$ to $C_{8}, D_{2}$ to $D_{8}, E_{2}$ to $E_{8}$ and $\mathrm{F}_{2}$ to $\mathrm{F}_{8}$ and then the $11^{\text {th }}$ and $12^{\text {th }}$ wells served as controls. Using a micropipette, place $200 \mu \mathrm{L}$ of the stock solution of extract 1 in A1 and B1 wells, $200 \mu \mathrm{L}$ of the stock solution of extract 2 in $\mathrm{C}_{1}$ and $\mathrm{D}_{1}$ wells while 200 $\mu \mathrm{L}$ of the stock solution of extract 3 in $\mathrm{E}_{1}$ and $\mathrm{F}_{1}$ (i.e. 2 wells were used for each extract). Meanwhile, $100 \mu \mathrm{L}$ of each stock or control solution were taken and later the serial dilutions of 2 to 2 were performed.

Afterwards, $100 \mu \mathrm{L}$ of $\mathrm{A}_{1} \mathrm{~B}_{1}, \mathrm{C}_{1} \mathrm{D}_{1}$ and $\mathrm{E}_{1} \mathrm{~F}_{1}$ wells were taken and transferred to $\mathrm{A}_{3} \mathrm{~B}_{3}, \mathrm{C}_{3} \mathrm{D}_{3}$ and $\mathrm{E}_{3} \mathrm{~F}_{3}$ wells, then from the previous wells $100 \mu \mathrm{L}$ were taken and were transferred to $\mathrm{A}_{4} \mathrm{~B}_{4}, \mathrm{C}_{4} \mathrm{D}_{4}, \mathrm{E}_{4} \mathrm{~F}_{4}$ wells. These solutions were thoroughly mixed and the same procedure continued till we reached $\mathrm{A}_{8} \mathrm{~B}_{8}, \mathrm{C}_{8} \mathrm{D}_{8}$ and $\mathrm{E}_{8} \mathrm{~F}_{8}$ wells. The last $100 \mu \mathrm{L}$ taken from these wells were removed and thrown away (Ngbolua et al. 2014e, f).

\section{iv. Determination of the minimum inhibitory concentration}

The growth observed in different wells containing extracts or controls were compared to that in the bacterial growth control well (well-having inoculum without extracts or antibiotics). For a test to be considered valid, an acceptable growth has to be observed in the control wells. If the growth is insufficient in these wells, there is a need to re-inoculate the microplate and after the addition of $5 \mu \mathrm{L}$ of TCC $2 \% \quad(2$, 3, 5triphenyltetrazoliumchloride) to the control wells then the minimum inhibitory concentration can be read. The principle of this method is based on the ability of living cells to reduce the tetrazolium salt to a red or formazan precipitate. The minimum inhibitory concentration was then read from the first wells showing no bacterial growth after 48 hours (Ngbolua et al. 2014e, f).

\section{c. Oral glucose tolerance test}

The study was carried out on an animal model consisting of 10 NMRI mice (male and female) subjected to temporary hyperglycemia by gavage of a glucose solution $\left(200 \mathrm{mg} \cdot \mathrm{mL}^{-1}\right)$. These 10 mice were divided into 3 groups as follows: a first group of two mice as a negative control (saline solution), a second group of three mice as a positive control (Glibenclamid $10 \mathrm{mg} \cdot \mathrm{Kg}^{-1}$ ) and the third group of five mice to be tested with the ethyl acetate extract $\left(500 \mathrm{mg} \cdot \mathrm{Kg}^{-1}\right.$ ). Blood glucose testing was performed using a contour TS blood glucose meter from the tail (Williamson et al. 1996). 


\section{d. Testing of normal blood sugar}

Mice were given a 24-hour pre-feed and then administered the extracts. Blood glucose was measured at $\mathrm{T}_{0}$, $\mathrm{T}_{1}, \mathrm{~T}_{2}, \mathrm{~T}_{3}$, and $\mathrm{T}_{4}$.

\section{e. Antihyperglycaemic activity}

In our study, we caused a temporary hyperglycemia in mice by oral administration of glucose (diluted to $10 \%$ in distilled water) at a dose of $4 \mathrm{~g} . \mathrm{Kg}^{-1}$ of body weight. The basic blood glucose of mice was first detected. The basal glucose level of mice was determined after 24 hours of fasting (Baseline) and then glucose was administered to the mice. After 30 minutes of glucose overload, the blood glucose was determined in order to note the temporary hyperglycemia (transient hyperglycemia should reach the maximal value 30 min after administration of glucose). And then three batches of mice according to sex, weight and especially temporary hyperglycemia were formed. Different batches of mice were treated as follows: A control batch treated with a saline solution at a dose of $0.9 \%$. A reference batch treated with Glibenclamid at $10 \mathrm{mg}^{-\mathrm{Kg}^{-1}}$ of body weight and a test batch treated with ethyl acetate extract at a dose of $500 \mathrm{mg} \cdot \mathrm{Kg}^{-1}$ of body weight.

\section{RESULTS AND DISCUSSION}

\section{A. Phytochemical Screening}

The result of the phytochemical screening is presented in the table below.

Table 1. Results of phytochemical screening of aqueous extracts of two plant leaves.

\begin{tabular}{lcc}
\hline \multirow{2}{*}{ Compounds } & \multicolumn{3}{c}{ PLANT EXTRACTS } \\
& Gymnanthemum coloratum & Terminalia ivorensis \\
\hline Total polyphenols & +++ & +++ \\
Flavonoids & +++ & +++ \\
Anthocyanins & +++ & - \\
Tannins & +++ & +++ \\
Leucoanthocyanins & +++ & ++ \\
Bound Quinones & ++ & +++ \\
Alkaloids & - & +++ \\
Saponins & +++ & +++ \\
\hline
\end{tabular}

Note : -, Absence of the researched substance; +, Low concentration of the researched substance; ++, High concentration of the researched substance; +++, The highest concentration of the researched substance.

From table 1 above, it is shown that $G$. coloratum leaves are rich in total polyphenols, tannins, flavonoids, linked quinones, saponins, leucoanthocyanins and anthocyanins while the total absence of alkaloids was noted. On the other hand, the leaves of $T$. ivorensis are rich in total polyphenol, tannins, flavonoids, linked quinones, saponins, leucoanthocyanins and alkaloids; however they are devoided of anthocyanins.

\section{B. Biological activities}

\section{a. Antisickling activity}

Figure 1 shows the phenotype of untreated (1a) and treated (1b) sickle cells respectively.
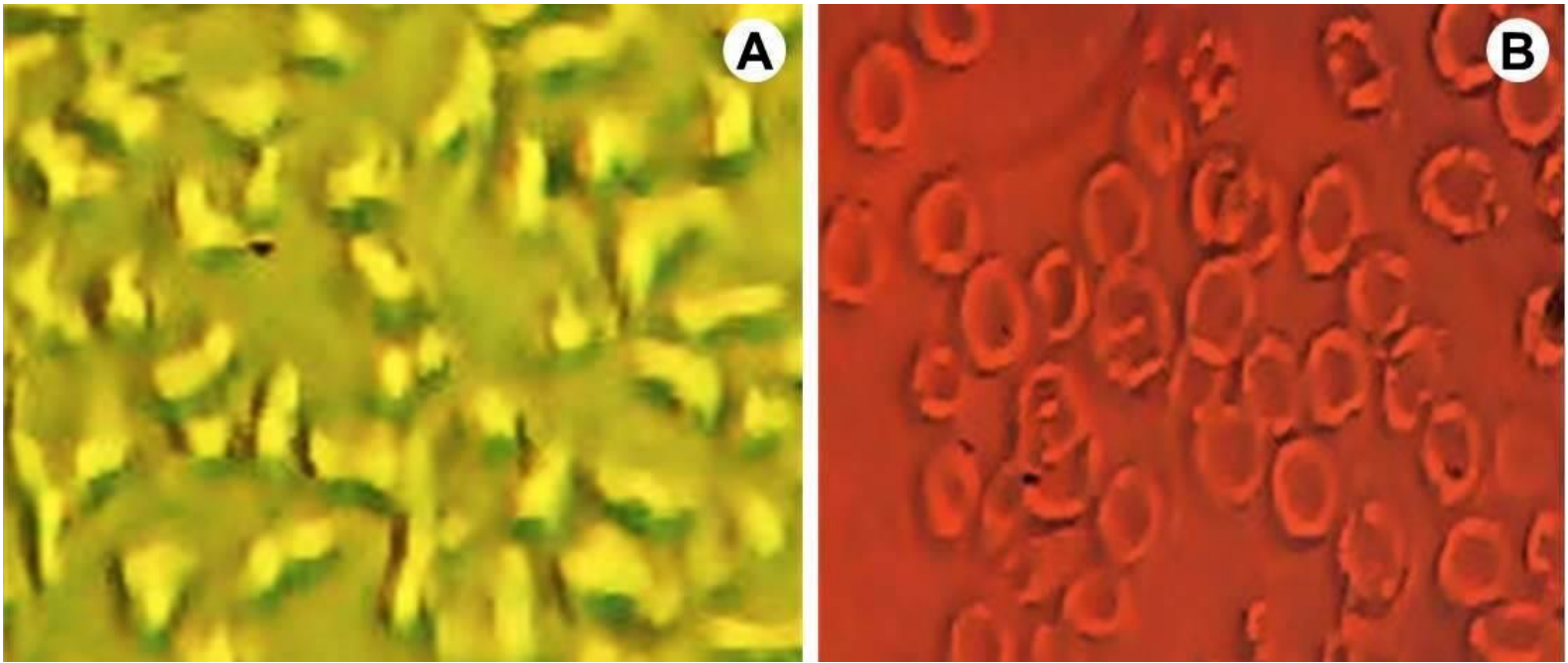

Figure 1. A, Optical micrographic of untreated SS blood; B, red blood cells treated with petroleum extract of Terminalia ivorensis $\left(50 \mu \mathrm{g} \cdot \mathrm{mL}^{-1}\right)$ [ $\mathrm{NaCl} 0.9 \% ; \mathrm{Na}_{2} \mathrm{~S}_{2} \mathrm{O}_{5} 2 \%$, X500]. 
As it can be noticed in the above figures, the red blood cells are of sickle cell phenotype showing that, the blood used was taken from a sickle cell patient. However, in the presence of petroleum extracts (b), sickle-cells revert to the normal circular and biconcave form. These results are consistent with previous observations (Ngbolua 2012, Mpiana et al. 2010).

The rate of normalization (Emmel test) of sickled cells in the presence of various extracts under conditions of isotonic hypoxia $\left(\mathrm{NaCl} 0.9 \%, \mathrm{Na}_{2} \mathrm{~S}_{2} \mathrm{O}_{5} 2 \%\right)$ is presented in table 2 below.

Table 2. Rate of normalization of sickled cells using Emmel test in presence of extracts.

\begin{tabular}{lcc}
\hline Extracts & \multicolumn{2}{c}{ RATE OF NORMALIZATION (RN) } \\
& Gymnanthemum coloratum & Terminalia ivorensis \\
\hline Petroleum ether extract & +++ & +++ \\
Ethyl acetate extract & ++ & +++ \\
Methanol & +++ & +++ \\
\hline Note:,- Inactive;,$+ 10<\mathrm{RN}<50 \%$ (low activity);,$++ 50<\mathrm{RN}<70 \%$ (higher activity); +++, \\
RN $>70 \%$ (the highest activity) [Source: Mpiana et al. 2010$]$
\end{tabular}

As described in table 2, the presence of organic extracts (petroleum ether, ethyl acetate and methanol) in $G$. coloratum and T. ivorensis demonstrate the normalization of the sickle-cells under conditions of hypoxia. This normalization of SS erythrocytes under conditions of hypoxia constitutes partially scientific evidence that justifies the integration of these two plants on the database of antisickling plants. The normalization of the SS blood erythrocytes treated with the extracts of these plants results in the reappearance of the circular form of sickled cells. These results are therefore are similar with those of previous works (Mpiana et al. 2007) as shown in figures $1 \mathrm{a}$ and $1 \mathrm{~b}$. However, it has to be noted that the extract of the ethyl acetate of G. coloratum showed a high antisickling activity with a normalization rate of between 10 and $50 \%$.

\section{b. Antibacterial Activity}

Tables 3 and 4 present the results of the antibacterial test.

Table 3. Effects of Terminalia ivorensis extracts on bacterial growth in vitro (Micro-dilution method, dye: TCC $2 \%$ ).

\begin{tabular}{lcccccc}
\hline $\begin{array}{l}\text { Concentration } \\
\left(\mu \mathrm{g} . \mathrm{mL}^{-1}\right)\end{array}$ & \multicolumn{3}{c}{ Escherichia coli A TCC } & $\mathbf{2 7 1 9 5}$ & \multicolumn{3}{c}{ Staphylococcus aureus ATCC 33591 } \\
EEP & EAE & MeOH & EEP & EAE & MeOH \\
\hline 4000 & + & - & - & - & - & - \\
2000 & + & + & - & - & - & - \\
1000 & + & + & + & - & - & - \\
500 & + & + & + & - & - & - \\
250 & + & + & + & - & - & - \\
125 & + & + & + & - & - & - \\
62.5 & + & + & + & - & - & - \\
\hline MIC & $>\mathbf{4 0 0 0}$ & $>\mathbf{2 0 0 0}$ & $>\mathbf{1 0 0 0}$ & $<\mathbf{6 2 . 5}$ & $<\mathbf{6 2 . 5}$ & $<\mathbf{6 2 . 5}$ \\
\hline
\end{tabular}

Note: +, bacterial growth (appearance of red color, conversion of colorless TCC to red formaztan); -, Absence of visible growth (the staining of the well is that of the extract); MIC, Minimum inhibitory concentration; ATCC, American Type Culture Collection; EEP, Petroleum ether extract; EAE, Ethyl acetate extract; MeOH, Methanolic extract.

This table shows that only $S$. aureus is susceptible to T. ivorensis leaf extracts (MIC $<62.5 \mu \mathrm{g}$. $\mathrm{mL}^{-1}$ ) while no effect was observed on E. coli.

Table 4. Effects of Gymnanthemum coloratum extracts on bacterial growth in vitro (Micro-dilution method, dye: TCC 2\%).

\begin{tabular}{lcccccc}
\hline $\begin{array}{l}\text { Concentration } \\
\left(\mu \mathrm{g} . \mathrm{mL}^{-1}\right)\end{array}$ & \multicolumn{2}{c}{ Escherichia coli ATCC } & $\mathbf{2 7 1 9 5}$ & \multicolumn{2}{c}{ Staphylococcus aureus ATCC 33591 } \\
\hline 4000 & EEP & EAE & MeOH & EEP & EAE & MeOH \\
2000 & + & - & - & - & - & - \\
1000 & + & - & - & - & - & - \\
500 & + & - & - & - & - & - \\
250 & + & + & - & - & - & - \\
125 & + & + & - & - & - & - \\
62.5 & + & + & - & - & - & + \\
\hline MIC & + & + & - & - & + & + \\
\hline NOt & $\mathbf{4 0 0 0}$ & $\mathbf{1 0 0 0}$ & $<62.5$ & $<62.5$ & $<62.5$ & $\mathbf{2 5 0}$ \\
\hline
\end{tabular}

Note: + , bacterial growth (appearance of red color: conversion of colorless TCC to red); -, Absence of visible growth (the staining of the well is that of the extract); MIC, Minimum inhibitory concentration; ATCC, American Type Culture Collection; EEP, Petroleum ether extract; EAE, Ethyl acetate extract; MeOH, Methanolic extract. 
From this table, it is shown that only $S$. aureus is sensitive to G. coloratum extracts (MIC $\leq 250 \mu \mathrm{g} . \mathrm{mL}^{-1}$ ). In fact, it is well known that extracts having a MIC less than $500 \mu \mathrm{g} \cdot \mathrm{mL}^{-1}$ are considered active and it is the case for these two plant extracts used in this study with respect to $S$. aureus (Molina-salinas et al. 2007). Contrary to $E$. coli, it should be noted that $S$. aureus is a positive gram bacterium, and its wall is thick (having several layers superimposed) while in $E$. coli the additional outer membrane would prevent the entrance of chemical compounds in the bacterial cell (Maligan \& Martinko 2007). The results obtained in this work indicated that the extracts of the two plants used in this study may constitute a source of new drugs against $S$. aureus, knowing that the sickle cell anemia patients are prone to repeated tissue infarction leading to a functional asplenia and are therefore exposed to frequent infections due to immune deficiency and phagocytic cell abnormality to cytokines (Bégué 2009). These two plants could be very useful in clinical trials.

\section{Antidiabetic activity}

The hyperglycemic test carried out with the ethyl acetate extract of T. ivorensis is presented in table 5 below.

Table 5. Antihyperglycemic test carried out with the ethyl acetate extract of Terminalia ivorensis.

\begin{tabular}{|c|c|c|c|c|c|c|}
\hline \multirow{2}{*}{ Drug/Extract } & \multicolumn{5}{|c|}{ Time (minutes) } & \multirow[b]{2}{*}{$\%$ RG } \\
\hline & $\mathbf{0}$ & 30 & 60 & 90 & 120 & \\
\hline $\mathrm{NaCl} 0.9 \%$ (Control) & $96 \pm 14.1$ & $106.5 \pm 14.8$ & $122.5 \pm 17.6$ & $108 \pm 1.41$ & $98.5 \pm 3.5$ & - \\
\hline $\begin{array}{l}\text { Glibenclamid } \\
\left(10 \mathrm{mg} \cdot \mathrm{kg}^{-1}\right)\end{array}$ & $68 \pm 10.5$ & $111 \pm 19.8$ & $185 \pm 15.08$ & $67 \pm 10.9$ & $62 \pm 14.3$ & 37.05 \\
\hline $\mathrm{EAE}\left(500 \mathrm{mg} \cdot \mathrm{kg}^{-1}\right)$ & $45.4 \pm 9.2$ & $93.4 \pm 17.7$ & $97.4 \pm 14.2$ & $74.2 \pm 10.08$ & $70.4 \pm 16.6$ & 28.53 \\
\hline
\end{tabular}

Following the above table, it is clearly displayed that the mean values of blood glucose after 120 minutes in untreated and treated mice were $98.5 \pm 3.5 \mathrm{mg} . \mathrm{dL}^{-1}(\mathrm{NaCl} 0.9 \%), 62 \pm 14.3 \mathrm{mg} . \mathrm{dL}^{-1}$ (Glibenclamid $10 \mathrm{mg} . \mathrm{Kg}^{-1}$ ) and $62 \pm 14.3 \mathrm{mg} . \mathrm{dL}^{-1}$ (ethyl acetate extract of $T$. ivorensis $500 \mathrm{mg} . \mathrm{Kg}^{-1}$ ) respectively. These results show that $T$. ivorensis has an antihyperglycaemic (hypoglycemic) activity. In fact, the reduction rate of glycaemia is of $28.53 \%$ versus $37.05 \%$ for Gilbenclamid. Up to date, numerous hypoglycemic plants have been identified by Fezan et al. (2008). The results on animal models showed that plant extracts could act through various mechanisms to lower blood glucose levels, thus reinforcing our results. To our knowledge, it is for the first time that the antisickling activity of $G$. coloratum and $T$. ivorensis is reported, thus validating the chemo-taxonomic approach used as a criterion for selecting these two plants while it is also for the first time that the antihyperglycaemic activity of $T$. ivorensis is reported. Henceforth, this validates the hypothesis that an antidiabetic plant would potentially possess an antisickling activity.

\section{CONCLUSION AND SUGGESTIONS}

The aim of this study was to assess the antisickling, antibacterial and anti-hyperglycemic potential of two taxonomic Congolese plants of which Gymnanthemum coloratum and Terminalia ivorensis. Both plants contain secondary metabolites capable of conferring the antisickling, antibacterial and anti-hyperglycaemic activities. Only S. aureus was sensitive to $T$. ivorensis and G. coloratum extracts. The extract of ethyl acetate of $T$. ivorensis is endowed with anti-hyperglycemic properties. Therefore, it would be necessary to carry out a toxicological study on both plants in order to include them in the traditional antisickling pharmacopoeia and also to consider carrying out an advanced phytochemical study on ethyl acetate extract of $T$. ivorensis in order to isolate bioactive molecules.

\section{ACKNOWLEDGEMENTS}

The authors thank The World Academy of Sciences (TWAS) for Grant No. 15-156 RG/CHE/AF/AC_GFR3240287018 and the Switzerland embassy at Kinshasa (DRC) for providing financial assistance to RESUD (Research for sustainable development/NGO).

\section{REFERENCES}

Bégué P (2009) Infection et Drépanocytose. Pathologie Biologie 47 (1): 19-25.

Bruneton J (1999) Pharmacognosie, Phytochimie et Plantes médicinales. Edition Technique et DocumentationLavoisier, 3e édition, Paris, pp. 421-499.

De boeck M, Jose G, Derrai K \& Wayne S (2012) Polyphenol and glucose homeostasis in humans, Journal of Academy of Nutrition and Dietetics 112(6): 808-815. 
Declerck M (2002) Diabète en image, outil pour l'éducation : association vaincre le diabète au Congo, éd. Médiaspaul, Kinshasa.

Declerck M (2003) Rôle de l'infirmier dans la prise en charge des diabétiques, éd. Médiaspaul, Kinshasa.

Fezan H, Rabi T, Guy M, Kohué CC \& Clejesson HB (2008) Etudes de quelques plantes thérapeutiques utilisées dans le traitement de l'hypertension artérielle et du diabète : deux maladies émergentes en Côte d' Ivoire. Sciences \& Nature 5(1): 39-48.

Kamba AS, Maznah I, Tengku A, Azni T \& Ibraimzuki A (2014) Toxicity relationship of sorafenib in Japanese patients with Renal cell Carcinoma and Hepatocellular Carcinoma Journal of Clinical Pharmacokinetics 53(2):185-196.

Kasali MF, Masunda TA, Madarhi KJ, Matambura AB, Tshibangu DST, Ngbolua KN, Kadima NJ and Mpiana PT (2016) Assessment of antidiabetic activity and acute toxicity of leaf extracts from Solanum nigrum L. (Solanaceae) in guinea-pigs. International Journal of Herbal Medicine 4(6): 14-19.

Katemo M, Mpiana PT, Mbala BM, Mihigo SO, Ngbolua KN, Tshibangu DST \& Koyange PR (2012) Ethnopharmacological survey of plants used against diabetes in Kisangani city (D.R. Congo). Journal of Ethnopharmacology 144: 39-43.

Kolling M, Winkley K \& Von Deden M (2010) “For someone who's rich, it's not a problem.” Insights from Tanzania on diabetes health-seeking and medical pluralism among Dar es Salam's urban poor. Globalization and Health 6: 8.

Madigan M \& Martinko J (2007) Brock, Biologie des microorganismes. 11e Edition. Pearson Education, Paris, France, $1047 \mathrm{pp}$.

Mangambu M, Van Diggelen R, Mwanga Mwanga J-C, Ntahobavuka H, Malaisse F \& Robbrecht E (2012) Etude ethnoptéridologique, évaluation des risques d'extinction et stratégies de conservation aux alentours du Parc National de Kahuzi Biega en R.D. Congo. International Journal of Tropical Geology, Geography and Ecology 36(1/2): 137-215.

Masunda TA, Mbala MB, Kayembe SJ, Longoma BF, Ngbolua KN, Tshibangu DST \& Mpiana PT (2014) Activité anti-hyperglycémique et antiradicalaire des extraits des fruits de Raphia gentiliana De Wild. (Arecaceae). International Journal of Biological \& Chemical Sciences 8(6): 2441-2451.

Mbodj NA (2003) Etude de l'activité antidiabétique des extraits Acétonique, Méthanolique et Hexadiques de Vernonia colorata (wild) Drake Composées chez des rats Wistar, Thèse de Doctorat. Université Cheikh Anta Diop, Dakar, Sénégal.

Molina-Salinas GM, Perez-Lopez A, Becerril-Montes P, Salazar-Aranda R, Said-Fernandez S \& De Torres NW (2007) Evaluation of the flora of Northern Mexico for in vitro antimicrobial and antituberculosis activity. Journal of Ethnopharmacology 109(3): 435-441.

Mpiana PT, Mudogo V, Ngbolua KN, Tshibangu DST, Shetonde OM \& Mbala BM (2007) In vitro Antisickling Activity of Anthocyanins from Ocimum basilicum L. (Lamiaceae). International Journal of pharmacology 3(4): 371-374.

Mpiana PT, Mudogo V, Ngbolua KN, Tshibangu DST \& Atibu EK (2010) In vitro Antisickling Activity of Anthocyanins Extracts from Morinda lucida Benth (Rubiaceae), In: Gupta VK \& Singh GD (eds) Medicinal Plants: Phytochemistry, Pharmacology and Therapeutics. Daya publishing house, Delhi, pp. 330337.

Mpiana PT, Masunda A, Longoma F, Tshibangu DST \& Ngbolua KN (2013) Antihyperglycemic activity of Raphia gentiliana De Wild. European Journal of Medicinal Plants 3(2): 233-240.

Ngombe KN, Mbombo PM, Maloueki U, Musuyu DM, Mutwale KP, Tujibikila AM, Ngbolua KN \& Kalenda DT (2013) Preliminary evaluation of antioxidant and antihyperglycemic activities of Isolona hexaloba (Pierre) Engl. \& Diels (Annonaceae) leaves. International Journal of Medicinal Plants, Photon 105: 242249.

Ngbolua KN (2012) Evaluation de l'activité anti-drépanocytaire et antipaludique de quelques taxons végétaux de la République Démocratique du Congo et de Madagascar, Thèse de Doctorat. Université de Kinshasa, République Démocratique du Congo.

Ngbolua KN, Fatiany PR, Robijaona B, Randrianirina AYO, Rajaonarivelo PJ, Rasondratovo B, Raharisololalao A, Moulis C, Mudogo V \& Mpiana PT (2014a) Ethno-botanical survey, Chemical composition and in vitro Antimicrobial activity of essential oils from the root bark of Hazomalania voyroni (Jum.) Capuron (Hernandiaceae). Journal of Advancement in Medical and Life Sciences 1(1): 1-6.

www.tropicalplantresearch.com 
Ngbolua KN, Mubindukila RN, Mpiana PT, Tshibangu DST, Ashande MC, Nzongola WXK, Baholy R \& Fatiany PR (2014b) Phytochemical screening, Antibacterial and Antioxidant activities of Anthocleista liebrechtsiana Wild \& T. Durand (Gentianaceae) originated from Democratic Republic of the Congo. Journal of Advancement in Medical and Life Sciences 1(3): 1-6.

Ngbolua KN, Bishola TT, Mpiana PT, Mudogo V, Tshibangu DST, Ngombe KN, Tshilanda DD \& Baholy R (2014c) In vitro antisickling and free radical scavenging activities of Pentaclethra macrophylla Benth. (Fabaceae). Journal of Advancement in Medical and Life Sciences 1(2): 1-6.

Ngbolua KN, Bishola TT, Mpiana PT, Mudogo V, Tshibangu DST, Ngombe KN, Ekutsu EG, Gbolo ZB \& Kabena OK (2014d) Ethno-pharmacological survey, in vitro antisickling and free radical scavenging activities of Carapa procera DC. stem bark (Meliaceae). Nova Journal of Medicaland Biological Sciences 2(2): $1-14$.

Ngbolua KN, Bishola TT, Mpiana PT, Mudogo V, Tshibangu DST, Ngombe KN, Ekutsu EG, Tshilanda DD, Gbolo ZB, Mwanangombo DT, Fatiany PR \& Baholy B (2014e) Ethno-botanical survey, in vitro antisickling and free radical scavenging activities of Garcinia punctata Oliv. (Clusiaceae). Journal of Advanced Botany \& Zoology 1(2): 1-7.

Ngbolua KN, Kabena ON, Lukoki FL, Mpiana PT, Ngombe KN, Fatiany RP \& Baholy R (2014f) Phytochemical Screening of some medicinal plants traditionally used by African Women in Kinshasa city (DR Congo) for their intimate hygiene and Evaluation of the $\mathrm{pH}$ of derived recipes. Journal of Modern Drug Discovery and Drug Delivery Research 1(3): 1-7.

Williamson EM, Okpoko DT \& Evans FJ (1996) Pharmacological methods in phytotherapy research. John Wiley and sons, Inc. Third Avenue, New York, USA. pp. 155-167. 